\title{
PENERAPAN MODEL PEMBELAJARAN CONNECTING, ORGANIZING, REFLECTING, EXTENDING UNTUK MENINGKATKAN HASIL BELAJAR MATEMATIKA SISWA KELAS VIII DI SMP NEGERI 02 KOTA BENGKULU
}

\author{
Lundy Eka Nurlianti ${ }^{1}$, Rusdi ${ }^{2}$, Agus Susanta ${ }^{3}$ \\ ${ }^{1}$ Program Studi Pendidikan Matematika, FKIP Universitas Bengkulu \\ email :1 lundyekanurlianti@gmail.com, ${ }^{2}$ rusdipendmat12@gmail.com, ${ }^{3}$ Agusunib@yahoo.com
}

\begin{abstract}
ABSTRAK
Penelitian ini bertujuan untuk mengetahui cara penerapan model Connecting, Organizing, Reflecting, Extending (CORE) sehingga dapat meningkatkan hasil belajar matematika siswa kelas VIII A SMP Negeri 02 Kota Bengkulu. Jenis penelitian yang dilaksanakan adalah Penelitian Tindakan Kelas (PTK) dengan tes hasil belajar siswa. Subjek dalam penelitian ini adalah siswa kelas VIII A SMP Negeri 02 Kota Bengkulu Semester Genap Tahun Ajaran 2017/2018 berjumlah 35 orang, terdiri dari 15 siswa laki-laki dan 20 siswa perempuan. Penelitian dilaksanakan dalam 3 siklus dari tanggal 5 April 2018 sampai dengan 21 mei 2018. Hasil penelitian menunjukkan bahwa penerapan model pembelajaran Connecting, Organizing, Reflecting, Extending (CORE) dapat meningkatkan hasil belajar matematika siswa. Peningkatan hasil belajar siswa dapat dilihat dari nilai rata-rata hasil belajar siklus I, II dan III secara berturut-turut 75,94; 82,17;84,46 dengan ketuntasan belajar klasikal pada siklus I, II, dan III secara berturut-turut yaitu 54,29\%, 77,14\%, 82,86\%.
\end{abstract}

Kata kunci : Hasil belajar, Model Pembelajaran Connecting,Organizing,Reflecting,Extending.

\begin{abstract}
The aim of this research was to know how to implement Connecting, Organizing, Reflecting, Extending learning model in order to improve mathematics learning result of students class $8 \mathrm{~A}$ in SMP Negeri 02 Bengkulu City. The type of this research is classroom action research with test for student learning result. Subjects in this research were students of class VIII A in SMP Negeri 02 Bengkulu city second semester of 2017/2018 academic year. Amount of subjects in this research were 35 students, consisted of 15 male students and 20 female students. The research was done in three cycle started on March 5th 2018 until May 21th 2018. The result of this research showed that implementation of Connecting, Organizing, Reflecting, Extending learning model can improve mathematics learning result of students. The improvement of students learning result can be seen from the average score on test for first, second and third cycle respectively which are 75,94; 82,$17 ; 84,46$ with classical mastery on first, second and third cycle are $54,29 \%, 77,14 \%$, and $82,86 \%$ respectevely.
\end{abstract}

Keywords :Learning result, Connecting, Organizing, Reflecting, Extending Learning Model.

\section{PENDAHULUAN}

Matematika merupakan suatu bidang ilmu yang mempunyai peranan penting dalam kehidupan sehari-hari. Oleh sebab itu, matematika dipelajari dari jenjang pendidikan dasar hingga perguruan tinggi. Matematika merupakan salah satu mata pelajaran yang selalu masuk dalam daftar mata pelajaran yang diujikan secara nasional, mulai dari tingkat SD sampai dengan SMA. Matematika memiliki konsep struktur dan hubungan-hubungan yang banyak menggunakan simbol. Sehingga siswa

Lundy, Rusdi, Agus

Penerapan Model Pembelajaran Connecting, Organizing, Eflecting, Extending Untuk Meningkatkan Hasil Belajar Matematika Siswa Kelas VIII di SMP Negeri 02 Kota Bengkulu 
sulit untuk memahami konsep yang terdapat dalam matematika dan cara menghubungkan simbol-simbol yang terdapat pada rumusrumus matematika. Oleh karena itu, siswa cenderung menghafal rumus tanpa mengetahui asal rumus tersebut dan siswa masih merasa kesulitan dalam memahami dan mengembangkan ide-ide yang mereka miliki dalam menyelesaikan masalah.

Rendahnya partisipasi siswa dalam pembelajaran akan mengakibatkan hasil belajar yang rendah, sehingga diperlukan tindakan yang baik dengan menerapkan strategi belajar atau metode atau model pembelajaran yang cocok dengan masalah yang dihadapi. Masalah di atas berhubungan dengan hasil belajar matematika siswa yang rendah dikarenakan kebanyakan tidak memahami konsep awal materi. Guru hendaknya memberikan solusi yang tepat seperti menghubungkan materi sebelumnya atau prasyarat dengan materi yang akan dipelajari sehingga lebih memudahkan siswa untuk memahami materi yang akan diberikan. Partisipasi siswa yang lebih aktif di dalam pembelajaran sangat memudahkan guru dalam menyampaikan materi dan tujuan pembelajaran.

Menurut Jacob dalam Yuniarti (2013) model pembelajaran Connecting, Organizing, Reflecting, Extending (CORE) adalah salah satu model pembelajaran yang berlandaskan konstruktivisme yang dapat mengaktifkan peserta didik dalam membangun pengetahuannya sendiri. Model pembelajaran CORE adalah suatu model pembelajaran yang memilki desain mengonstruksi kemampuan siswa dengan cara menghubungkan dan mengorganisasikan pengetahuan, kemudian memikirkan kembali konsep yang sedang dipelajari dan dapat memperluas pengetahuan selama proses pembelajaran (Lestari \& Yudhanegara, 2015:52). Melalui tahapantahapan model pembelajaran CORE pada materi geometri sangat cocok untuk menumbuhkan sikap aktif belajar siswa.

Pada penelitian ini langkah-langkah model pembelajaran CORE yang digunakan merupakan penggabungan dan modifikasi dari langkah-langkah menurut Suyatno (2009: 67), Shoimin (2014:39), dan Dwijayanti \& Kurniasih (2014), yaitu sebagai berikut:

1. Guru menyampaikan tujuan pembelajaran, mempersiapkan siswa, dan memberikan motivasi.

2. Melalui serangkaian pertanyaan dari guru, siswa melakukan apersepsi untuk mengingat materi sebelumnya atau prasyarat untuk dihubungkan dengan materi yang akan dipelajari.(Connecting)

3. Siswa diberi waktu untuk mengerjakan LKS tahap Connecting.

4. Pengorganisasian ide-ide untuk memahami materi yang dilakukan oleh siswa dengan bimbingan guru.(Organizing)

5. Siswa diberi waktu untuk mengerjakan LKS tahap Organizing.

6. Guru membagi siswa kedalam beberapa kelompok secara heterogen yang terdiri dari 4-5 siswa tiap kelompoknya.

7. Siswa mendiskusikan jawaban LKS tahap Connecting dan Organizing dengan kelompok masing-masing untuk memahami materi yang diberikan oleh guru. (Reflecting)

8. Guru membantu siswa menyimpulkan dengan bahasa sendiri tentang apa yang mereka peroleh dari pembelajaran melalui latihan-latihan sederhana untuk membiasakan siswa dengan permasalahan yang ada melalui diskusi kelompoknya. (Reflecting)

9. Guru meminta perwakilan beberapa kelompok untuk mempresentasikan hasil diskusi kelompok masing-masing. (Reflecting)

10. Guru memberikan kuis kepada siswa untuk memperluas pengetahuan mereka mengenai materi yang baru dipelajari secara individu. (Extending)

\section{METODE PENELITIAN}

Penelitian ini merupakan Penelitian Tindakan Kelas (PTK) yang terdiri dari 3 siklus. Setiap Siklus terdiri dari empat tahap 
yaitu 1) Tahap Perencanaan, 2) Tahap Pelaksanaan, 3) Tahap Pengamatan, 4) Tahap Refleksi. Subjek penelitiannya adalah seluruh siswa kelas VIII A yang berjumlah 35 orang terdiri dari 15 orang siswa laki-laki dan 20 orang siswa perempuan di SMP Negeri 02 Kota Bengkulu Tahun Pelajaran 2017/2018.

1. Perencanaan

Perencanaan disebut juga tahap menyusun rancangan tindakan peneliti untuk menentukan titik atau fokus persitiwa yang perlu mendapatkan perhatian khusus untuk diamati, kemudian membuat sebuah instrumen pengamatan untuk membantu peneliti merekam fakta yang terjadi selama tindakan berlangsung.

2. Pelaksanaan

Pada tahap ini, pelaksanaan yang merupakan implementasi atau penerapan isi rancangan, yaitu mengenakan tindakan di kelas.

3. Pengamatan

Pengamatan dilakukan pada waktu tindakan sedang dilakukan. Sambil melakukan pengamatan, guru pelaksana mencatat sedikit demi sedikit apa yang terjadi agar memperoleh data yang akurat untuk perbaikan siklus berikutnya.

4. Refleksi

Tahap refleksi merupakan kegiatan untuk mengemukakan kembali apa yang sudah dilakukan baik hal yang dirasa sudah berjalan baik dan bagian mana yang dirasa belum baik.

Tes hasil belajar digunakan untuk memperoleh data tentang hasil belajar siswa di setiap siklus. Tes hasil belajar yang diperoleh dari setiap siklus dianalisis secara deskriptif untuk mengetahui nilai rata-rata hasil belajar siswa dan persentase ketuntasan belajar klasikal siswa. Dengan rumus perhitungan sebagai berikut:

a. Nilai Rata-rata Hasil Belajar Siswa

Nilai rata-rata hasil belajar siswa secara keseluruhan atau nilai rata-rata kelas dapat ditentukan dengan menggunakan rumus:

$$
\bar{x}=\frac{\Sigma \mathrm{X}}{\boldsymbol{N}}
$$

Sumber: Sudjana (2016:109)

Keterangan:

$\bar{x}=$ nilai rata-rata kelas (mean)

$\Sigma \mathrm{X}=$ jumlah semua nilai siswa

$\mathrm{N} \quad=$ jumlah siswa

b. Persentase Ketuntasan Belajar Klasikal Siswa

$$
\rho=\frac{\Sigma \text { Siswa yang tuntas belajar }}{\Sigma \text { siswa }} \times 100 \%
$$

Sumber : Aqib (2014:41)

Keterangan:

$\rho=$ persentase ketuntasan belajar klasikal siswa

c. Peningkatan Keberhasilan Tes

Peningkatan Keberhasilan tes hasil belajar untuk setiap siklusnya dapat dihitung dengan menggunakan rumus $N$-gain (Normalizedgain). Adapun rumusnya adalah sebagai berikut.

$$
N-\operatorname{gain}(g)=\frac{S_{\text {post }}-S_{\text {pre }}}{S_{\text {maks }}-S_{\text {pre }}}
$$

Sumber: Adaptasi dari Rahmaniati dan Supramono (2015:196)

Keterangan:

$\mathrm{N}$-gain $(\mathrm{g}) \quad$ : Peningkatan keberhasilan tes hasil belajar

$S_{\text {post }} \quad$ : Rata-rata nilai siklus akhir

$S_{\text {pre }} \quad:$ Rata-rata nilai siklus awal

$S_{\text {maks }} \quad$ : Rata-rata nilai siklus maksimal

Dimana tingkat perolehan skor dikategorikan atas tiga kategori sebagai berikut.

$\mathrm{g}<0,3=$ Belum ada peningkatan

$0,3 \leq \mathrm{g} \leq 0,7=$ ada peningkatan

$\mathrm{g}>0,7 \quad=$ sangat ada peningkatan

\section{HASIL DAN PEMBAHASAN}

Hasil belajar peserta didik diperoleh dari nilai tes yang diberikan pada akhir setiap siklus. Tes belajar dilakukan untuk mengetahui pemahaman peserta didik terhadap materi yang telah diajarkan pada tiap siklus. Berikut

Lundy, Rusdi, Agus 
ini hasil analisis terhadap hasil belajar peserta didik pada tabel berikut:

Tabel 1

Hasil Belajar Peserta Didik Siklus I, II, dan III

\begin{tabular}{|c|c|c|c|c|}
\hline Siklus & $\begin{array}{c}\text { Nilai } \\
\text { rata- } \\
\text { rata }\end{array}$ & $\begin{array}{c}\text { Jumlah } \\
\text { Peserta } \\
\text { Didik } \\
\text { yang } \\
\text { tuntas }\end{array}$ & $\begin{array}{c}\text { Hasil } \\
\text { Belajar } \\
\text { Klasikal }\end{array}$ & Keterangan \\
\hline I & 75,94 & 19 & $54.29 \%$ & $\begin{array}{c}\text { Belum } \\
\text { tercapai }\end{array}$ \\
\hline II & 82,17 & 27 & $77,14 \%$ & $\begin{array}{c}\text { Belum } \\
\text { tercapai }\end{array}$ \\
\hline III & 84,46 & 29 & $82,46 \%$ & Tercapai \\
\hline
\end{tabular}

Data pada tabel 1 di atas menunjukkan bahwa hasil belajar peserta didik dilihat dari nilai rata-rata dan ketuntasan belajar klasikal peserta didik meningkat setiap siklus. Nilai rata-rata peserta didik pada siklus I yaitu 75,94, pada siklus II nilai rata-ratanya menjadi 82,17 , dan nilai rata-rata peserta didik kembali meningkat menjadi 84,46 pada siklus III. Namun pada nilai minimum dan nilai maksimum tidak mengalami peningakatan. Nilai minimum lebih banyak mengalami penurunan yang signifikan yaitu 20 poin yang terjadi dari siklus I ke siklus II. Hal ini dikarenakan peserta didik dengan inisial NE masih terlihat pasif selama kegiatan diskusi berlangsung sehingga guru mengajak peserta didik lainnya yang sekelompok dengannya untuk lebih aktif lagi dalam berdiskusi antar anggota kelompok dan juga guru memberikan dorongan serta penguatan kepada peserta didik tersebut. Tidak hanya dalam kegiatan berdiskusi tetapi semua kegiatan pembelajaran.

Pada tabel 1 juga menunjukkan bahwa ketuntasan belajar klasikal mencapai 82,46\%. Hal ini berarti pada siklus III ketuntasan belajar klasikal peserta didik sudah mencapai kriteria keberhasilan tindakan yaitu $\geq 80 \%$. Secara klasikal hasil belajar peserta didik selalu mengalami peningkatan setiap siklusnya. Sedangkan, hasil belajar tiap individu pada setiap siklus, memiliki perkembangan hasil belajar yang sangat beragam. Keberagaman tersebut dapat dilihat pada gambar berikut:

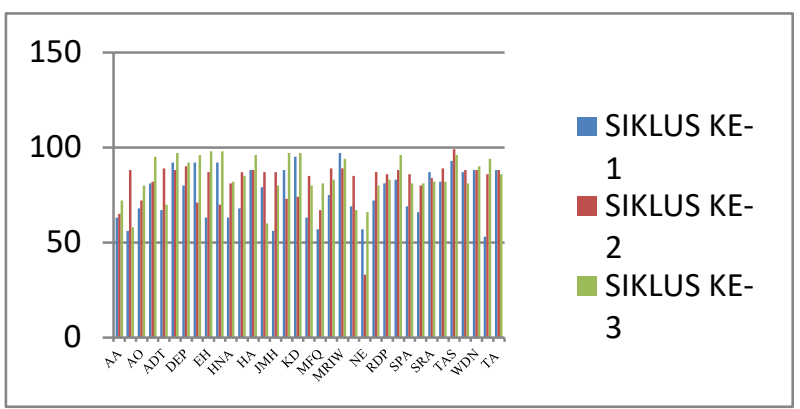

Gambar 1

Grafik Perkembangan Nilai Tes Siklus Peserta Didik

Pada gambar 1 menunjukkan bahwa perkembangan nilai peserta didik secara individu tidak selalu meningkat setiap siklus. Peningkatan nilai setiap siklus hanya terjadi pada 12 siswa, sedangkan 22 siswa lainnya mengalami perubahan nilai yang naik turun. Artinya persentase peserta didik yang mengalami perubahan nilai yang naik turun dari siklus I hingga siklus III yaitu $62,85 \%$, dengan persentase peserta didik yang mengalami penurunan nilai dari siklus I ke siklus II ada 7 orang atau $20 \%$, persentase peserta didik yang mengalami penurunan dari siklus II ke siklus III ada 12 orang atau 34,28\% dan dari gambar tersebut terlihat ada 1 orang peserta didik berinisial SRN yang mengalami penurunan dari siklus I sampai siklus III.

Selanjutnya, kenaikan hasil belajar peserta didik yang signifikan baik dari siklus I ke siklus II maupun dari siklus II ke siklus III. Dari siklus I ke siklus II terdapat 23 orang peserta didik yang mengalami kenaikan nilai hasil belajar yang signifikan. Sedangkan dari siklus II ke siklus III terdapat 19 orang peserta didik yang mengalami kenaikan nilai hasil belajar yang signifikan. Persentase peserta didik secara individu yang tidak pernah mencapai nilai ketuntasan belajar $\geq 75$ selama tes siklus I hingga siklus III hanya 2 orang peserta didik atau hanya $5,71 \%$. 
Dari analisis tes siklus I, II. dan III, peserta didik banyak mengalami penurunan nilai dari siklus II ke siklus III sebanyak 14 orang peserta didik yaitu AH, ADT, HWA, JVV, JMH, MYC, MGAS, NAF, OS, RDP, SPA, SRN, TH, TAS, WRS, TA. Hal ini disebabkan peserta didik lebih memahami materi di siklus II daripada siklus III. Karena materi siklus II masih mempunyai kemiripan dengan materi siklus I, yaitu bangun ruang kubus dan balok seperti unsur-unsur dan rumus volume serta kubus dan balok termasuk ke dalam prisma. sedangkan rumus-rumus limas berbeda dengan rumus-rumus prisma. Kemudian peserta didik yang mengalami kenaikan nilai dari siklus I ke siklus II dalam kategori perubahan nilai naik turun sebanyak 24 orang peserta didik yaitu AA, AH, AO, AZM, ADT, DEP, EH, HNA, HWA, JVV, JMH, MYC, MFQ, MGAS, NAF, OS, RDP, SN, SPA, SM, TH, TAS, WRS, YAW, disebabkan karena peserta didik banyak yang sudah memahami materi prisma yang memilki kemiripan dengan materi siklus I, yaitu bangun ruang kubus dan balok yang sudah mereka pelajari. Sehingga banyak peserta didik yang mendapatkan nilai tuntas $(\geq 75)$.

Analisis hasil tes pada siklus I menunjukkan bahwa terdapat 19 peserta didik yang mencapai KKM ( $\geq 75)$. Faktor yang menyebabkan peserta didik tidak mencapai nilai KKM (tidak tuntas) adalah soal yang diberikan kepada peserta didik terlalu banyak dan pemahaman konsep materi sebelumnya yang berkaitan dengan soal seperti teorema pythagoras masih belum dipahami. Terlihat pada soal tes no 2 berikut ini:

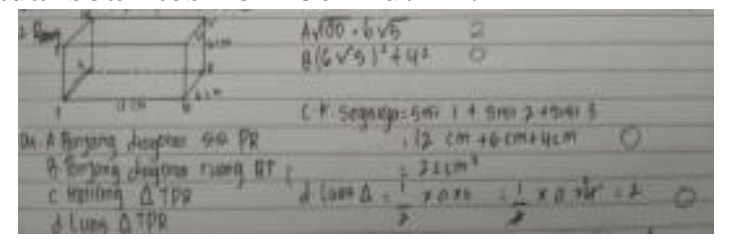

Gambar 2

Contoh Kesalahan dalam menjawab Soal Tes Siklus I

Gambar 2 diatas memperlihatkan soal yang meminta peserta didik untuk mencari panjang diagonal sisi dan ruang serta keliling dan luas dari segitiga yang terbentuk dari panjang diagonal sisi/ruang yang telah dicari sebelumnya. Sehingga untuk soal ini terdapat kaitannya dengan pertanyaan soal sebelumnya. Apabila peserta didik tidak bisa menjawab pertanyaan (a) pada soal nomor 2 , maka untuk pertanyaan selanjutnya (b,c,d pada soal nomor 2) peserta didik dipastikan tidak bisa menyelesaikan soal tersebut. Kesalahan lainnya yang dilakukan oleh peserta didik yaitu memberikan jawaban kosong pada lembar tes jawaban untuk soal yang diberikan sehingga peserta didik tidak mendapatkan nilai sebesar (26 poin).

Pada siklus II masalah peserta didik yang belum memperoleh nilai ketuntasan diatas nilai $\mathrm{KKM} \geq 75$ yaitu berjumlah 8 orang yang masih menjadi perhatian peneliti, walaupun jumlah peserta didik yang belum mencapai ketuntasan sudah berkurang dari sebelumnya. Untuk nilai rata-rata dan persentase ketuntasan belajar klasikal peserta didik sudah mengalami peningkatan dari sebelumnya. Pada siklus II ini, terdapat 1 peserta didik yang tidak mengalami peningkatan nilai dari siklus I. Pada soal tes siklus II, sebagian dari 8 peserta didik yang salah dalam menjawab soal no 4 dan sebagian lagi menggambar jaring-jaring prisma yang tidak sesuai dengan ukuran yang telah ditentukan pada soal no 2. Seperti gambar 3 :
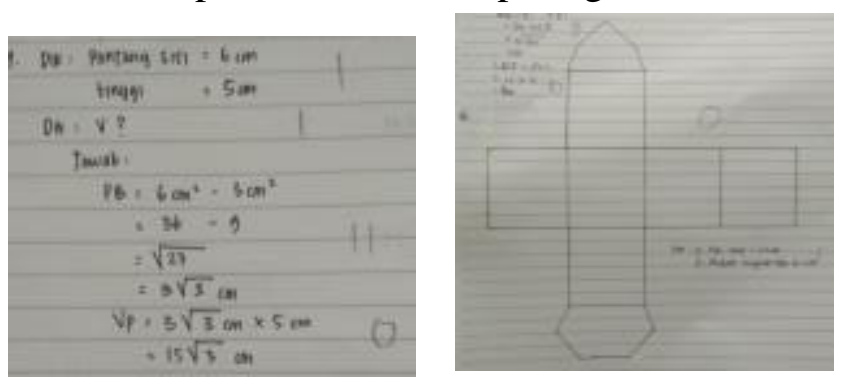

\section{Gambar 3}

\section{Contoh Kesalahan dalam Menjawab Soal Tes} Siklus II

Gambar 3 menunjukkan kesalahan yang ditunjukkan pada gambar di atas merupakan soal materi jaring-jaring dan volume prisma. Soal tes pada siklus II ini peserta didik 
menjawab soal belum sesuai dengan jawaban yang diharapkan, selain itu faktor yang menyebabkan peserta didik belum mencapai nilai ketuntasan minimum yaitu peserta didik masih kurang teliti dengan jawaban yang ditulisnya dalam menghitung. Dan juga dalam hal menggambar masih terlihat belum menguasai konsep dasarnya.

Pada siklus III persentase ketuntasan belajar klasikal peserta didik meningkat menjadi $82,86 \%$. Hal ini berarti 29 peserta didik telah memiliki nilai $\geq 75$ atau telah mencapai nilai ketuntasan minimum. Hasil tes menunjukkan tes akhir siklus sudah memenuhi indikator keberhasilan yang diinginkan. Pada siklus III ini sudah meningkat, seperti gambar 4 berikut:

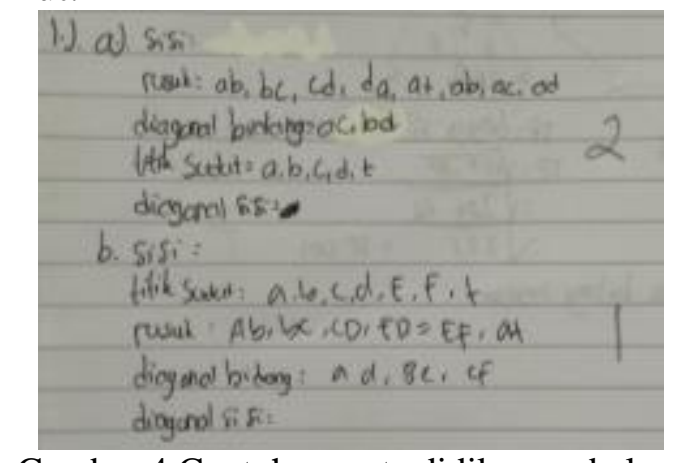

Gambar 4 Contoh peserta didik yang belum menjawab soal tes siklus III dengan tepat.

Gambar 4 menunjukkan pada soal tes siklus III terlihat peserta didik masih belum bisa menentukan dan menyebutkan bagianbagian dari unsur-unsur limas secara keseluruhan.

Guru memberikan beberapa tindakan diantaranya memberikan soal latihan pada akhir tahap organizing dan menuliskan hal-hal penting apa saja yang telah dipelajari tentang materi pada saat itu di papan tulis kemudian peserta didik mencatat di buku catatannya untuk dipelajari lagi dirumah. Dengan dilakukannya tindakan tersebut, maka pada tes siklus III diperoleh nilai rata-rata 84,46 atau secara ketuntasan klasikal belajarnya mencapai $82,86 \%$. Berdasarkan hasil tes siklus I, siklus II, dan siklus III tindakan yang dilakukan yaitu dengan diterapkan pada model pembelajaran
Connecting, Organizing, Reflecting, Extending (CORE) menjadikan peserta didik aktif.

Hasil belajar peserta didik mengalami peningkatan dengan rata-rata hasil belajar peserta didik 84,46 pada siklus III dan ketuntasan belajar klasikal peserta didik mencapai $82,86 \%$. Berdasarkan data tersebut menunjukkan bahwa penerapan model pembelajaran CORE dapat meningkatkan hasil belajar peserta didik kelas VIII A SMP Negeri 02 Kota Bengkulu. Nilai hasil belajar peserta didik setiap siklusnya mengalami peningkatan, namun masih ada peserta didik mengalami penurunan hasil belajar. Peserta didik yang mengalami peningkatan hasil belajar adalah peserta didik yang memahami materi dan konsep awalnya, dan aktif dalam kegiatan pembelajaran setiap siklusnya.

\section{PENUTUP \\ Simpulan}

Penerapan model pembelajaran Connecting, Organizing, Reflecting, Extending (CORE) untuk meningkatkan hasil belajar matematika siswa pada materi bangun ruang sisi datar di kelas VIII A SMP Negeri 02 Kota Bengkulu daa beberapa tindakan yang dilakukan oleh peneliti yaitu,

a. Guru memberikan Lembar Kerja Siswa (LKS) kepada setiap peserta didik untuk lebih memahami materi dan sebagian tahapan yang akan mereka lakukan dan juga membantu peneliti dalam menjelaskan materi pada tahap Connecting dan Organizing.

b. Memberikan soal latihan dan kuis kepada peserta didik untuk lebih memahami materi yang dipelajari, serta agar peserta didik dapat terbiasa dalam menyelesaikan permasalahan yang berkaitan dengan materi bangun ruang sisi datar.

c. Memberikan motivasi kepada peserta didik untuk yakin dan percaya akan kemampuan yang dimilikinya dalam menyelesaikan soal kuis yang diberikan.

Peningkatan juga terjadi pada hasil belajar peserta didik dengan nilai rata-rata 
dari siklus I, siklus II, hingga siklus III secara berturut-turut adalah 75,$96 ; 82,17$; 84,46. Dan ketuntasan belajar klasikal dari siklus 1 hingga siklus III secara berturutturut adalah $54,29 \% ; 77,14 \% ; 82,46 \%$.

\section{Saran}

Berdasarkan penelitian yang telah dilakukan oleh peneliti, maka saran yang dapat diberikan oleh peneliti, yaitu:

1. Guru harus lebih mempersiapkan lagi bahan-bahan ajar ataupun materi yang akan dijelaskan kepada peserta didik serta memberikan lebih banyak latihan-latihan soal. Dan juga lebih banyak membaca referensi tentang bahan ajar yang baik dan menarik bagi peserta didik.

2. Guru harus lebih mampu dalam mengelola kelas dengan baik agar peserta didik dapat fokus dalam belajarnya. Guru juga harus memperhatikan kedisiplinan waktu dalam melakukan setiap tahapan-tahapan pembelajaran, agar tujuan pembelajaran yang ingin diinginkan dapat tercapai.

3. Guru mata pelajaran matematika sebaiknya menerapkan model Connecting, Organizng, Reflecting, Extending (CORE) pada pokok bahasan yang cocok dan sesuai dengan kurikulum sekolah sebagai variasi model pembelajaran sehingga peserta didik tidak merasa bosan.

\section{DAFTAR PUSTAKA}

Aqib, Z., Jaiyaroh, S., Dinianti, E., \& Khotimah, K. 2014. Penelitian Tindakan Kelas Untuk Guru, SD, SLB, TK. Bandung: CV. Yrama Widya.

Dwijayanti, A., \& Kurniasih, AW.2014. Komparasi Kemampuan Pemecahan Masalah Matematika Antara Model PBI dan CORE Materi Lingkaran. e-jurnal Pendidikan Matematika, Vol. 3, No. 3, hlm. 190-195. (http://journal.unnes.ac.id/sju/index.php/u jme), diakses 28 Desember 2017)

Lestari, K. E., \& Yudhanegara, M. R. 2015. Penelitian Pendidikan Matematika. Bandung: PT. Refika Aditama.

Shoimin, Aris. 2014. 68 Model Pembelajaran Inovatif dalam Kurikulum 2013. Yogyakarta: Ar-Ruzz Media.

Sudjana, N. 2016. Penilaian Hasil Proses Belajar Mengajar. Bandung: Remaja Rosdakarya.

Suyatno. 2009. Menjelajah Pembelajaran Inovatif. Sidoarjo:Masmedia Buana Pustaka.

Yuniarti, Santi. 2013. Pengaruh Model CORE Berbasis Kontekstual Terhadap Kemampuan Pemahaman Matematik Siswa. e-jurnal Program Studi Pendidikan Matematika STKIP Siliwangi Bandung.

(http://publikasi.stkipsiliwangi.ac.id/files/ 2013/01/Santi-Yuniarti.pdf, diakses 28 Desember 2017). 